\title{
A Research of the Finding and Distribution Law of Taisui in Modern China
}

\author{
Chao-Jiang Wang1, Shi-Qing Wang2* \\ ${ }^{1}$ Hebei Plant Genetic Engineering Center, Shijiazhuang, China \\ ${ }^{2}$ Shijiazhuang No.44 Middle School, Shijiazhuang, China \\ Email: ${ }^{\text {Ihswchj@163.com }}$
}

Received 10 March 2015; accepted 6 April 2015; published 9 April 2015

Copyright (C) 2015 by authors and Scientific Research Publishing Inc.

This work is licensed under the Creative Commons Attribution International License (CC BY).

http://creativecommons.org/licenses/by/4.0/

(c) (i) Open Access

\section{Abstract}

The academic world is still uncertain about the classification of Taisui. It is debating whether Taisui is living or not, myxomycete complex or fungi. The passage studies the 228 finding reports of Taisui in modern China. It confirms that the first finding time of Taisui in modern China is 1963, and the first reported time is $\mathbf{1 9 9 2}$. Taisui has been found in 25 administrative divisions. Taisui occurs the most times in Shandong Province. Besides, provinces where Taisui has been found most times are in northern China. Finding locations of Taisui vary from place to place. Taisui is most often found in normal earth layer, with different burying depth. Taisui is mainly found through seeing, tramping, and digging. Taisui findings lack subjective motivations and are connected with the life and production of the finders. Conclusion: Taisui is an object growing in earth layer.

\section{Keywords}

Taisui, Finding Law, Distribution Law, China in Modern Times

\section{Introduction}

"Guai Rou" is a lump of object, which is resilient, growing, and mainly comes from soil layer. Moreover, it is hard to tell whether "Guai Rou" is a kind of plant or a kind of animal. Since a mass of "Guai Rou" was found in Wei River of Zhou Zhi County of Shaanxi Province [1], this mysterious object is constantly reported. Since the morphological characteristics of this mysterious object are similar to the description of Taisui in ancient China literature [2], gradually this object is named as Taisui (Figure 1).

Although many researchers try to study the classification of Taisui, it is still debating whether Taisui is living or not, and it is myxomycete complex, fungi or bacteria. The researchers in Northwest University are the first

\footnotetext{
${ }^{*}$ Corresponding author.
} 

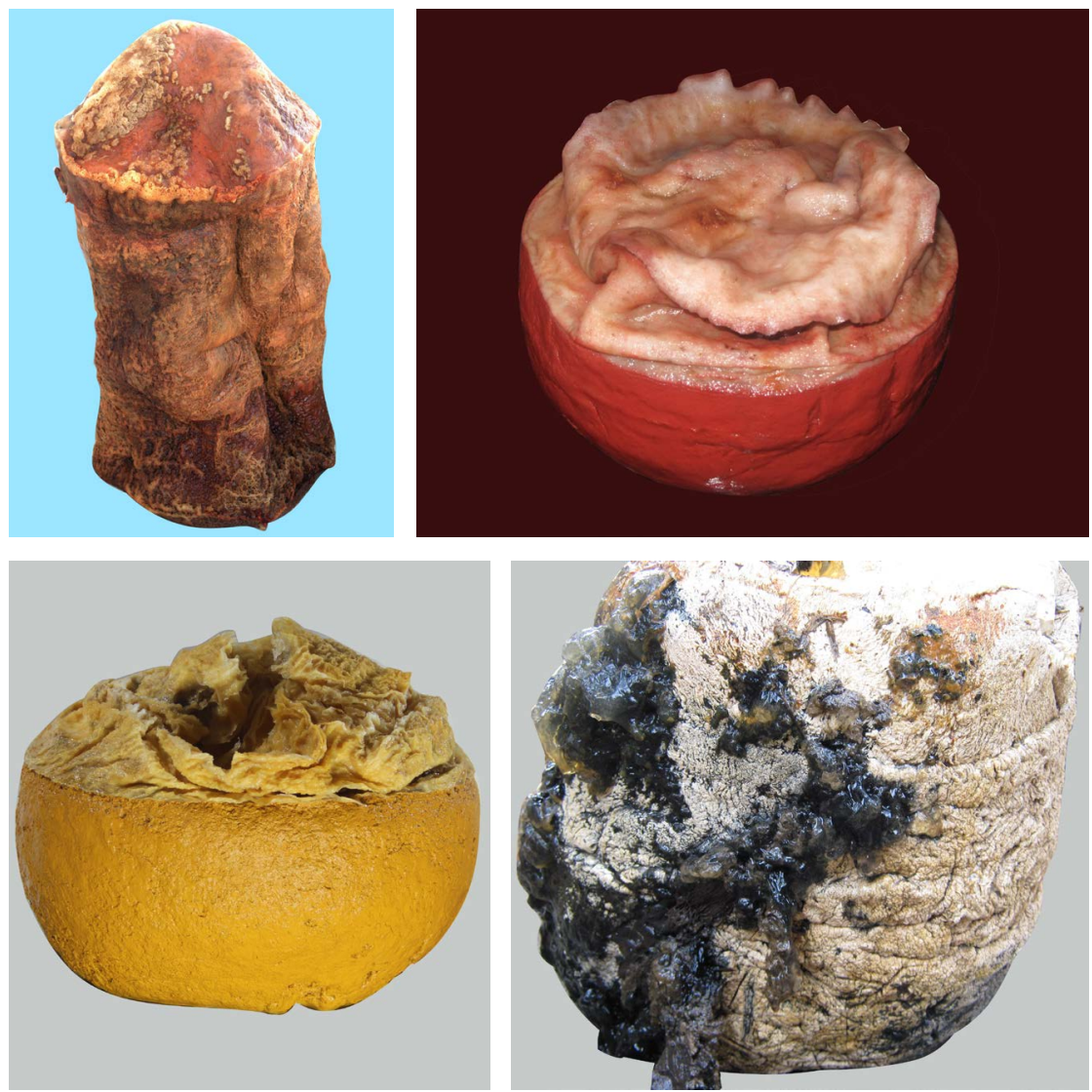

Figure 1. Taisui of different morphology in modern China.

ones to have Taisui specimen, and assume Taisui is myxomycete complex. After conducting a systematic research of Taisui fungi diversity [3] and bacteria diversity [4], they switch to the conclusion that Taisui is an unknown object mainly made up of polyvinyl alcohol and some polysaccharide, covered with myxobacteria, mould, and bacillus [5]. Therefore, Taisui becomes a puzzle in academic world. Academically speaking, the above research ignores a fact that Taisui exists in soil sludge. Thus, there are many different kinds of bacteria adhered to Taisui, both in and out. In different conditions, bacterial community structures change. It is incorrect to judge Taisui classification according to the research results of this Taisui specimen.

The passage adopts a new research route and chooses the Taisui reports in recent 31 years as research object. After studying the information as to Taisui finding time, finding ways, finding motivations, finding locations, it is attempted to induce a general and systematic principle of Taisui.

\section{Materials and Methods}

\subsection{Research Materials}

Taisui finding reports are from August 22, 1992 to December 31, 2013. Except that the Taisui report of Shaanxi Zhouzhi comes from a magazine, other reports are from the network database (including electronic version of newspapers). The Taisui reports on the websites are stored according to time sequence. If the same finding is reported by a number of media, the first report is chosen. If the first reports cannot be found, earlier forwarded reports are chosen. On the account of the comprehensiveness and convenience of non-video reports, it is chosen as the main data source for analysis and studying.

\subsection{Data Extraction and Processing of Taisui Finding Reports}

After the completion of the collection of reports, repeated reports are eliminated by comparison and discrimination. 
For each report, information are respectively extracted from reports, such as the reported date, finding date, the name and address of Taisui founders, finding location, finding ways, buried depth. The information is then classified and summarized.

Taisui reported date and Taisui finding date are classified according to the corresponding finding year.

Taisui finding reports are classified by the number of times. 1 times of reporting signifies 1 Taisui finding, irrespective of the number of Taisui found each time.

Taisui finding locations are classified according to its belonging administrative divisions.

Taisui finding locations are classified according to the domain (water) morphology, types of adhesive substrate. These location types are divided into conventional soil, river area, lake-pond area, sea area, drainage channel, and a variety of adhesive substrate. Conventional soil covers plateau, mountains, plains, hills, valleys and so on, including both cultivated and non-cultivated land; river area includes rivers, streams, river banks and dry streambed; lake-pond area includes ponds, reservoirs, lake waters, cofferdam, dyke, dry bare shoal and lake bottom; sea area includes the offshore waters and beaches.

Taisui finding ways refer to the first perceived way of the exposure or the existence of Taisui.

The vertical distribution of Taisui is sampled by the reports that confirm the existence in earth and its burying depth. It is then researched the distribution law of Taisui at different depth $(\leq 0.2 \mathrm{~m}, 0.2-1 \mathrm{~m}, 1-2 \mathrm{~m}, 2-3 \mathrm{~m}$, $\geq 3 \mathrm{~m}$ ).

\subsection{Analysis of the Taisui Finding Reasons and Motivations}

Reports where Taisui was dug in conventional soil are selected as research samples. First, the initial motive of the digging is classified into associations of rural, urban, industrial production and other activities. Then these four sections are classified in accordance with specific daily life and production activities, in order to find out the original motivation of digging Taisui. In this way, it is tried to infer the subjective factors in finding Taisui.

\section{Results and Analysis}

\subsection{Taisui Reporting Times and Taisui Finding Time}

\subsubsection{Total Reporting Times}

By the end of December 31, 2013, 228 Taisui finding reports are collected, including 1 magazine report, 223 Webpage reports (including the electronic version of newspapers, news), 4 video reports.

\subsubsection{First Taisui Reporting Time}

Taisui was reported for the first time on August 22, 1992, when the farmer Wu Fenglian and her son Du Zhanmeng found Taisui in Wei River in Zhouzhi County of Shaanxi Province [1]. The finding was shot into a feature film called "Uncover the mystery of Taisui" by the CCTV science and education channel in 1996.

\subsubsection{First Taisui Finding Time}

It is held by a lot of media that August 22, 1992 (Taisui is found in Zhouzhi Shaanxi) is the first finding time in modern China. However, by a comparison of Taisui reporting time and Taisui finding time, the relationship between these two factors has different patterns of manifestation in different years. In most cases, the manifestation is consistent, namely Taisui finding time and Taisui reporting time are the same. However, many Taisui findings before 2002 were reported after year 2002, Taisui finding time in modern China was advanced to 1963 by a report in 2013, about 30 years ahead (Figure 2).

\subsubsection{Continuity of Taisui Finding Time}

In the 24 years from 1990 to 2013, except year1991, 1995, 1998, 2001, the left 20 years all have Taisui finding reports. Especially, the 12 years after 2002 presents a continuous Taisui finding situation. Besides, Taisui finding times in each year also increased, up to 37 times the most, 4 times the least.

\subsection{Statistics of Taisui Finding Reports According to Provinces}

The 224 Taisui non-video finding reports are classified by administrative divisions, as can be seen from Table 1 . 


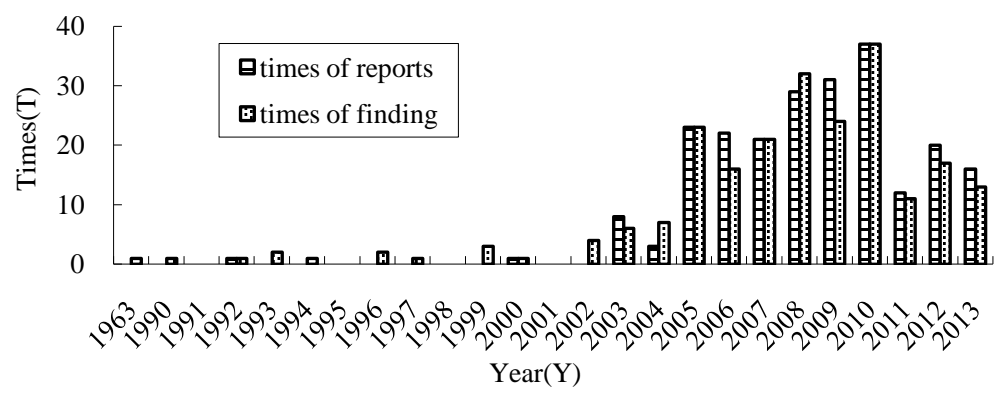

Figure 2. Reporting times and finding times in years.

Table 1. Administrative divisions of Taisui finding reports.

\begin{tabular}{|c|c|c|}
\hline Administrative divisions & Reporting times & Ratios (\%) \\
\hline Hubei & 1 & 0.45 \\
\hline Sichuan & 1 & 0.45 \\
\hline Anhui & 2 & 0.89 \\
\hline Hunan & 2 & 0.89 \\
\hline Qinghai & 2 & 0.89 \\
\hline Yunnan & 2 & 0.89 \\
\hline Fujian & 3 & 1.34 \\
\hline Gansu & 3 & 1.34 \\
\hline Guangdong & 3 & 1.34 \\
\hline Jiangxi & 3 & 1.34 \\
\hline Ningxia & 3 & 1.34 \\
\hline Zhejiang & 3 & 1.34 \\
\hline Beijing City & 4 & 1.79 \\
\hline Tianjin City & 5 & 2.23 \\
\hline Shanxi & 6 & 2.68 \\
\hline Henan & 8 & 3.57 \\
\hline Jiangsu & 9 & 4.02 \\
\hline Shannxi & 9 & 4.02 \\
\hline Hebei & 11 & 4.91 \\
\hline Xinjiang & 15 & 6.70 \\
\hline Inner Mongolia & 16 & 7.14 \\
\hline Heilongjiang & 22 & 9.82 \\
\hline Jilin & 22 & 9.82 \\
\hline Liaoning & 33 & 14.73 \\
\hline Shandong & 36 & 16.07 \\
\hline
\end{tabular}




\subsubsection{Taisui Was Nearly Nationwide Distributed in China}

Taisui has been reported in 25 administrative divisions, accounting for $80.65 \%$ of 31 provinces, municipalities, autonomous regions in China.

\subsubsection{Taisui Is Mostly Found in Northern China}

Taisui appears the most time in Shandong Province, which is altogether 36 times, accounting for $16.7 \%$ of all reporting times. The followings are Liaoning, Jilin, Heilongjiang, Inner Mongolia, Xinjiang. All of the above provinces are in Northern China. Taisui finding times in these provinces are more than 15 times, accounting for $64.29 \%$ of all reporting times.

\subsection{Morphology Law of Taisui Finding Locations}

Of 224 reports, 222 have descriptions of Taisui finding locations. Taisui finding locations are classified and summarized, as is demonstrated by Figure 3.

\subsubsection{Diversity of the Morphology of Taisui Finding Locations}

Taisui is found in conventional soil, river area, lake-pond area, sea area, drainage channel, wells, and waste heap. The above locations almost cover a large variety of the morphology of land surface, and overlap with human activities regions. Taisui found in waste heap and strange rock heap bear obvious traces of human's picking up and transferring Taisui. The original finding locations of this Taisui are very likely to be ground surface, mountain area, or river area.

\subsubsection{Repetition of Taisui Finding Location Types}

Locations where Taisui is found more than 2 times are wells, waste heap, drainage channel, sea area, lake-pond area, river area and conventional soil. Repetition of Taisui finding locations means that characteristically similar Taisui are found in the morphologically similar places, even though the two places are very distant. It greatly improves the credibility of the finding, suggesting that Taisui is indeed an objective existence.

\subsubsection{Taisui Is Found the Most Times in Conventional Soil}

The number of reports where Taisui is found in conventional soil occupies $62.16 \%$ of all the reports. If reports where Taisui is found in the soils of river bank, pond bank, lake bank, drainage channel, canal embankment, cofferdam are taken into consideration, the proportion rises to $69.37 \%$. Further, taking into account the water scouring action, the proportion of Taisui found in the soil layer will be even higher. Soil layer is the location type where Taisui is found the most times. In other words, Taisui is an object mainly existing in soil layer.

\subsection{Ways of Finding Taisui}

In the 222 Taisui finding reports with descriptions of Taisui finding locations, Taisui finding ways can be further sorted into seeing, tramping, digging, dragging and soaking. The results are sorted as Table 2 according to the ways of finding Taisui.

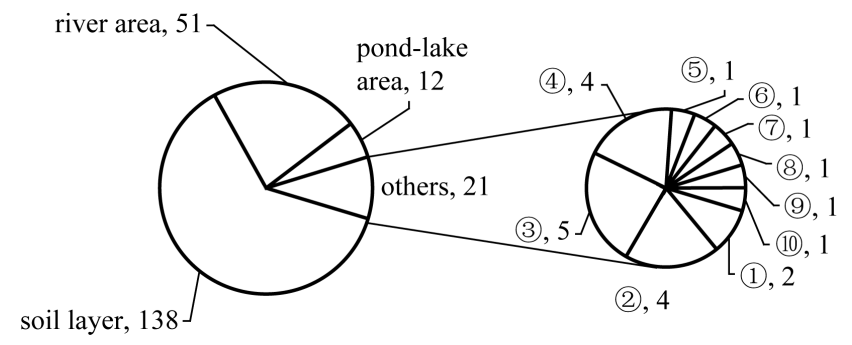

Figure 3. Statistics of finding location types of Taisui. (1)wells, (2) drainage channel, (3) sea area, (4) waste heap, (5) dunghill, (6) house roof, (7) house crack, (8) tree roots, (9) cave, (10) strange rock). 
Table 2. Statistics of finding ways of Taisui in different finding region types.

\begin{tabular}{|c|c|c|c|c|c|c|c|c|c|c|c|c|c|}
\hline Finding ways & $\begin{array}{l}\text { Conventional } \\
\text { soil layer }\end{array}$ & $\begin{array}{l}\text { River } \\
\text { area }\end{array}$ & $\begin{array}{l}\text { Lake } \\
\text { area }\end{array}$ & Wells & $\begin{array}{l}\text { Drainage } \\
\text { channel }\end{array}$ & Sea area & $\begin{array}{l}\text { Garbage } \\
\text { Dump }\end{array}$ & Dunghill & Roof & $\begin{array}{l}\text { Door } \\
\text { crack }\end{array}$ & Roots & Cavities & $\begin{array}{l}\text { Strange } \\
\text { rocks }\end{array}$ \\
\hline Seeing picking & 43 & 35 & 8 & - & & 2 & 1 & & 1 & 1 & 1 & 1 & - \\
\hline Seeing digging & 11 & 4 & - & - & 1 & - & - & - & - & - & - & - & - \\
\hline Tramping digging & 14 & 6 & - & - & - & - & - & - & - & - & - & - & - \\
\hline Digging soil & 70 & 6 & 1 & 1 & 2 & 2 & 3 & 1 & - & - & - & - & - \\
\hline Dragging & - & - & 3 & 1 & 1 & 1 & - & - & - & - & - & - & - \\
\hline Soaking & - & - & - & - & - & - & - & - & - & - & - & - & 1 \\
\hline
\end{tabular}

\subsubsection{Seeing}

Seeing means the method of finding Taisui by eye luck. This method is promoted by 3 aspects: one is the range of eyesight; the second is an attraction by the outside morphology and color of Taisui which is different from the surrounding objects; the third is the exploration psychology, or the curiosity to find out. In this condition, Taisui encountered basically exists freely and is easy to find. If some part of Taisui is covered by earth, it should be dug out. Therefore this method is further sorted into 2 ways, that is, picking after being seen and digging after being seen. The reported finding-times of the first kind is 93 cases, making up $41.89 \%$ of the total number (222 times), and the reported finding-times of the latter is 16 cases, making up $7.21 \%$ of the total.

\subsubsection{Tramping}

Tramping means the method of finding Taisui by foot luck. This method has 2 promoting factors. Besides tramping and touching, the curiosity of finding Taisui also owes to Taisui's specific elasticity which is different from surrounding objects. This method is reported 20 times, making up 9.01\% of the total. The Taisui tramped mostly exists in shallow soil layer, or is partly exposed, or is buried by thin earth. Thus, Taisui in this case is easy to pick or dig.

\subsubsection{Digging}

Digging means the way of finding Taisui during moving earth. This method also needs 3 promoting factors. It may happen that the diggers just right digs out Taisui, or that Taisui spreads out the earth surface, or that Taisui is dug out the second time when filling the earth back. As a result, in this finding way, the digger and the finder sometimes are the same person, sometimes are not. Taisui finding times of this way is 86 cases, making up $38.74 \%$ of the total number.

\subsubsection{Dragging}

Dragging means the method of finding Taisui during fishing activities. This method of finding is reported to be 6 times, making up $2.70 \%$ of the total.

\subsubsection{Soaking}

Soaking means the way of finding Taisui by soaking strange stone. The promoting reasons are very strange. It is strange that the dehydrated and wizened Taisui is brought back as a strange stone because of the strange morphplogy. It is even strange that the stone is suck up and softened after soaking in water, and that the stone is recognized as Taisui. This is strange plus strange. Only one case belongs to this kind, making up $0.45 \%$ of the total.

\subsection{The Motivation of Finding Taisui by Digging}

The motivations of 70 Taisui findings by regular earth layer digging are sorted by the type of life and production category, which is summarized as Table 3.

According to Table 3, the main motivations of digging earth for Taisui are human life and production-construction activities.

The rural digging reasons include common farm work, construction and facility installation activities etc. 
Common farm work refers to ploughing and digging, plowing, hoeing, planting trees and harvesting; rural constructing refers to digging foundation for building houses, taking out and using earth; rural facilities includes burying electronic rod, repairing underground water pipe, digging methane pool. Urban digging reasons include constructions of buildings, bridges, roads and attached facilities construction activities. Industrial production digging reasons include digging wells and mining. The number of Taisui discovered during the 3 production and construction activities make up $95.71 \%$ of the 70 finding reports. If the number of the Taisui found during looking for scorpion is considered, the proportion arises to $97.14 \%$. This proves that production and construction activities are the fundamental motivation of digging for Taisui. The opposite is also true. To put it another way, even if there are no digging activities, the fact that Taisui exists in earth layer can not be changed.

\subsection{The Vertical Distribution of Taisui in Earth Layer}

In the reports of Taisui findings by digging, 47 of them have descriptions of the burying depth. The summary according to burying depth is shown in Figure 4 and it can be seen that:

\subsubsection{The Depth Difference of Taisui Distribution Is Great}

The distribution depth includes different earth layers from plowing layer $(\leq 0.2 \mathrm{~m})$, raw earth layer $(0.2-1 \mathrm{~m})$ and dead earth layer $(\geq 1 \mathrm{~m})$ etc. which vary greatly both in morphology and nutritional level. Among the 4 reports where the distribution depth is deeper than $3 \mathrm{~m}$, there is 1 Taisui in $10 \mathrm{~m}, 1$ in $20 \mathrm{~m}, 1$ in $117 \mathrm{~m}$ and 1 in melting cave of several hundred meters deep.

\subsubsection{The Main Distribution Depth of Taisui Is Inner Earth Layer of $1 \mathrm{~m}$}

In the $1 \mathrm{~m}$ earth layer, the number of the Taisui reports in cultivation layer is about 16 times, making up 34.04\% of the known-depth reports and the number of the Taisui reports between $0.2-1 \mathrm{~m}$ layer is 20, making up $42.55 \%$. The Taisui finding reports of those two earth layers reached 36 times in total, making up $76.59 \%$ of the total number. Moreover, this depth layer is also the layer that is frequently dug and used for human life and production activities.

\subsection{Subjective Motivations Are Lacked in Finding of Taisui}

This is clearly shown in Table 3. Among the 70 reports of Taisui findings by digging, only in case where finders look for Taisui on purpose, making up $1.43 \%$ of the total. The other finding reports show that the main motivation of digging clearly lies in construction rather than looking for Taisui. It can also be seen from Table 2 that

Table 3. Human activities types of Taisui findings through digging normal earth layer.

\begin{tabular}{cccccccccc}
\hline & \multicolumn{3}{c}{ Rural area } & & Urban area & Industrial production & Other activities \\
\cline { 2 - 9 } Digging reasons & Farming & Buildings & Facilities & Buildings & Facilities & Drill & $\begin{array}{c}\text { Mining } \\
\begin{array}{c}\text { Scorpion } \\
\text { searching }\end{array}\end{array} \begin{array}{c}\text { Digging } \\
\text { Taisui }\end{array}$ & $\begin{array}{c}\text { Dragging } \\
\text { in soil }\end{array}$ \\
\hline Reporting times & 21 & 12 & 3 & 24 & 5 & 1 & 1 & 1 & 1 \\
Proportion (\%) & 30.00 & 17.14 & 4.29 & 34.29 & 7.14 & 1.43 & 1.43 & 1.43 & 1.43 \\
\hline
\end{tabular}

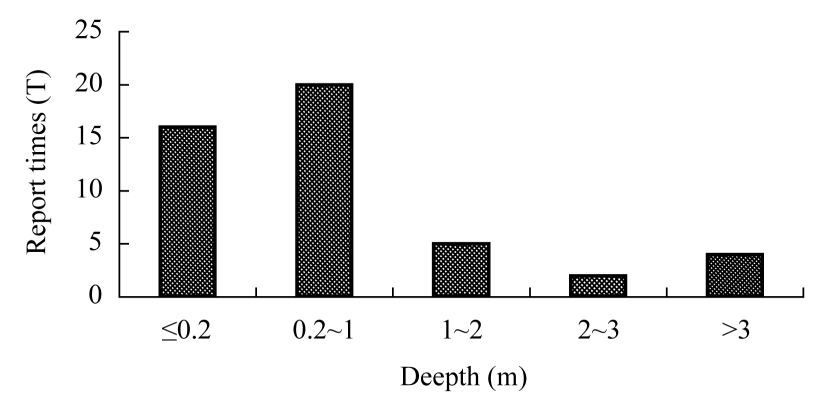

Figure 4. Taisui distributions in different soil layers. 
besides finding Taisui by digging, in all other Taisui finding ways, the finders do not have subjective consciousness of looking for Taisui, and the action motivation and discovery results are separate. Of the aim of dragging and soaking action, the first lies in production and the latter lie in relaxation and entertainment instead of finding Taisui. Tramping is the action during realizing other goals, such as working, fishing and calling. Seeing is also an unconscious action without finding aims. As a result, one character of Taisui finding is that Taisui finding fact does not accompany with finding motivation.

\section{Discussion}

\subsection{Taisui Is an Objective Thing Rather than Man-Made Gel}

As to the belongings of Taisui, for many times it is inferred as abandoned gel after construction, although this possibility can not be excluded. After an analysis of 222 Taisui finding reports, it is discovered that Taisui finding is not alone and it is obviously repeated. It is repeated during human-frequent farm work and in deserted mountains. It is repeated in mature earth layer and in deep raw and dead earth layer. In addition, the repetition characters of different burying depth are also clear, and these findings were not driven by subjective consciousness but by accident. So it is clear that not all modern Taisui are man-made gel [5]. Then what is that left? It can not be denied that it is maybe an objective thing .Some research shows that Taisui is an object of high protein, low fat and rich in calcium, ferritin and zinc and other microelement [6].

\subsection{Taisui Is Born in Earth and Should Be Distributed All around the World}

Among the 222 Taisui reports with descriptions of Taisui finding locations, except those picked from ground, 138 Taisui findings are related with digging, making up 69.37\% of the total. This showed that earth is Taisui's burying material. In other words, Taisui is buried or born in earth. If provinces where Taisui is found more than 15 times are regarded as centered strip to radiate outwards in China, Taisui distributes to the southeast-most in Fujian Province, southwest-most in Sichuan Province. Taisui distribution area spans throughout China, both north-south and east-west. According to this ratio, it is predicted that Taisui should also exist in North Korea, Mongolia, Russia, Iran, and Turkey. As a result, Taisui distribution should be worldwide, at least not in China alone.

\section{Conclusion}

In summary, Taisui is an objective thing rather than man-made gel. Taisui is born in earth and should be distributed all around the world. Taisui is an unknown species or an unknown new form of life. Taisui needs further researching.

\section{References}

[1] Zou, J.P. and Zhen, X. (1994) Who Can Reveal the Mystery of “Guai Rou”. China Science and Technology Information, 4, 45-47.

[2] Duan, C.S. (1981) Youyang Zazu. Zhong Hua Press, Beijing.

[3] Dai, L. (2007) Assessment of Myxomycete and Fungal Diversity of the "Myxomycete Complex. Ph.D. Thesis, Northwest University, Xi'an.

[4] Wang, X. (2007) A Primary Study of Bacterial Diversity and Antibacterial Function of Large Myxomycete Complex. Ph.D. Thesis, Northwest University, Xi'an.

[5] Zheng, K.Y. and Dong, Z.L. (2010) Preliminary Study of the Unknown Object of “Taisui”. Journal of Northwest University, 40, 1012-1016.

[6] Zhu, C.Y., Bai, T.T., Jiang, J.S., et al. (2011) The Study of Biological Composition of Taisui. Microbiology Magazine, 31, 1-5. 